\title{
特集「環境効率」
}

解 説

\section{富士通グループにおける製品への環境効率指標の適用 布施健介}

\section{Utilization of Eco-efficiency Factor for Products in Fujitsu Group}

Kensuke FUSE

\begin{abstract}
Synopsis: The development of product functionalities and service is a critical element for IT products while the reduction of environmental loads is another challenge for manufactures. Eco-efficiency, coupling with the economical and environmental improvements at the same scale, is a beneficial indicator to pursue the sustainable yield.

This paper shows one of the approaches applied by Fujitsu Group showing personal computer as a main example. In order to express the benefits or service of products, product functions or hardware specifications are used as base data. Environmental loads are calculated based on LCA method. Especially, EcoLeaf environmental label, which is the Japanese Type III label, and Fujitsu's internal assessment methods are introduced. In addition, the integration of environmental loads by applying LIME is another characteristic of our approach. In closing, we believe that LCA is not only the effective tool to evaluate and review our products internally, but also the essential communication media connecting suppliers and customers by showing Ecoefficiency, Type III label and social cost.
\end{abstract}

KeyWords: LCA, Eco-efficiency, Factor X, Personal Computer, EcoLeaf Type III Label

1.はじめに “IT製品における環境効率算出の意義”

富士通グループでは、新製品の設計時から環境負荷の低 減を図る独自の製品環境アセスメントおよび、省資源化・ リサイクル設計・化学物質含有規制・省エネルギーなどの

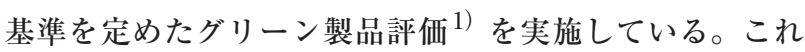
らの評価の中でLCAの実施を組み込んでおり、2002年度 には富士通単体で、2003年度には富士通グループにおい て全ての新規開発製品でグリーン製品化を達成することで、 現在全ての新規開発製品でLCAが活用されている（Figure.1)。

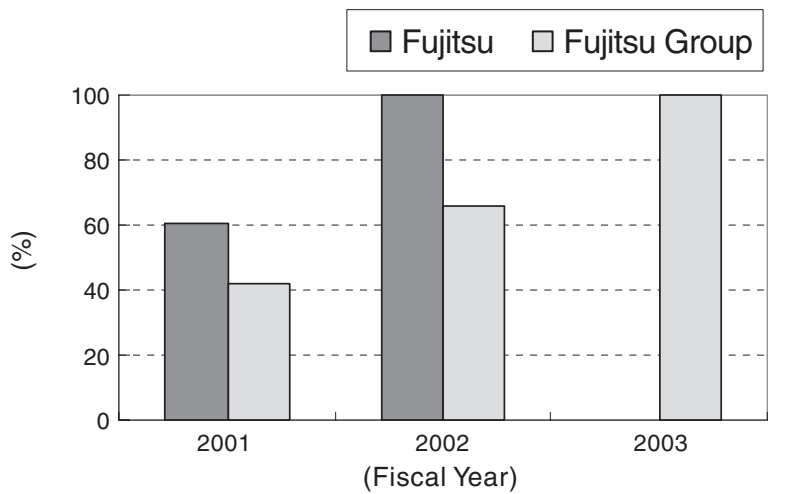

Figure.1 Green Product development results (Fujitsu Group)
LCAによる評価が社内で浸透していく一方、環境負荷 のみならず、他の要素も踏まえて結果を表現したいという 要望が生じた。富士通グループで取り扱うIT製品や半導 体は、短期間で性能・機能が著しく向上する製品群が多い (Figure.2)。通常、性能・機能の向上に伴い、その分仕事 量が増加するため消費電力が上がる傾向があり、設計段階 では如何にこの消費電力を抑えるかが大きな課題となって いる。しかしながら、環境負荷評価に焦点を当てている

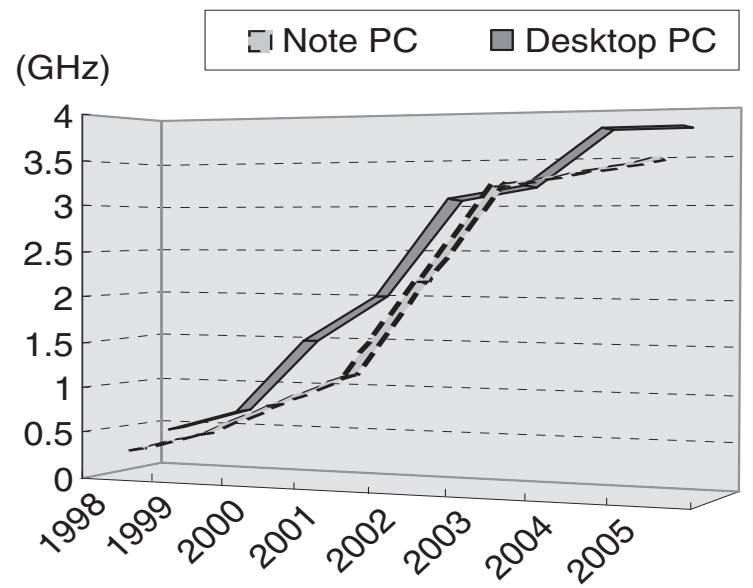

Figure.2 Transitions of CPU clock number of personal computer 
LCAでは、この努力が数字となって現れてこない。具体 的に言うと、例えば半導体設計者が性能・機能を向上させ た後の、消費電力や製品質量維持への戦いがLCAでは表 現できなかった。

そこで環境効率またはファクターの有意義性が発揮され る。従来の LCAに加元、製品の性能・機能の側面を数值 化し同時に指標で表すことで、その努力を数值化すること が始めて可能となった。製品設計で環境負荷の低減と経済 （性能・機能向上といった製品の便益）の発展を両立させ るために、特にIT製品において、この指標は大変重要な 意味を持っていると考えられる。

\section{LCA と環境効率の位置づけ}

製品の環境効率指標を論じる際、「環境効率は環境負荷 の増減をごまかすための企業側の言い訳になってしまわな いか」という議論を問われることがある。環境効率では、 環境負荷に加え、同時に価值・便益の増減も算出因子に入 っているため、一つの数字となったとき個々がぼやけてし まうという久点の指摘である。当社においては、環境負荷 の曖昧さが出ないように、基本的なスタンスとしてLCA による評価結果を最重要視している。前述にもあるように、 全ての新規開発製品でLCAを実施し、環境負荷評価を熟 虑した上で、さらに性能・機能の向上度を表現したい製品 群に対して、環境効率という別の角度から評価を行うので ある。加えて、環境効率内の環境負荷を算出する際におい ても、IT製品の場合使用ステージ以外の環境負荷が高い ことが多々あるため、特定ステージではなく包括的な評体 で結果を示している。

次に外部への発信であるが、Figure.3に表すように、富 士通グループでは社内における製品 LCA 算出活動をべー スとし、環境効率の他に、ビジネスユーザー向けなど第三 者の認証を介したいときは、社団法人産業環境管理協会の 運営する「エコリーフ環境ラベル（以下エコリーフ）」を 取得する。さらに一般消費者などへの理解度促進を高める ため、環境負荷を金額に換算するLIME統合化指標を活用 した社会コスト算出 ${ }^{1)}$ 、さらにはライフサイクルコスト ${ }^{2)}$ へも取り組み、内部活用と共にユーザーに応じ最も適切と 思われるLCA 情報を発信することに努めている。

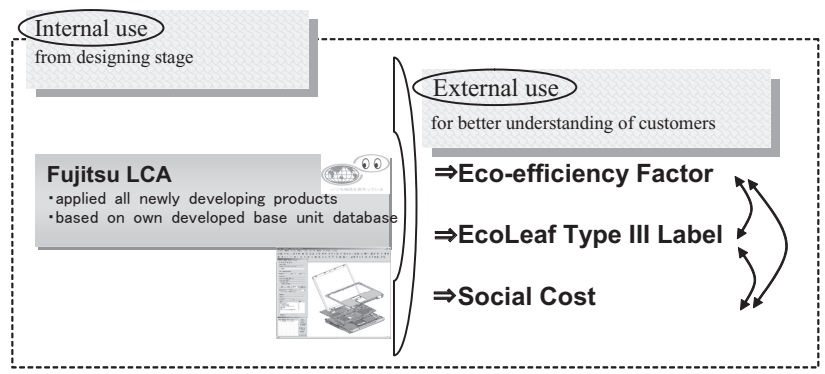

Figure.3 Various environmental indicator of product in Fujitsu group

\section{3. 富士通グループの「環境効率ファクター」}

富士通グループでは、経済産業省が設置した資源生産性 調查委員会に当初より参画し、「環境効率」や「ファクタ 一X」の開発を手がけてきた。そして、2002年度の環境 報告書 ${ }^{3)}$ に、パソコンを事例とした環境効率を初めて揭 載し、その後も学会及び環境展示会を通じて算出方法詳細 の発表を、携帯電話やスキャナーなどの様々なコンシュー マー製品に対象を拡張して行っている。

一般に製品に関する環境効率の算出は、分子に製品の価 値をとり、分母に環境負荷を用いて表現し、ファクターに 関しては評価製品の環境効率と、基準製品の環境効率の比 率をとっている ${ }^{4)}$ 。

\section{環 境 効 率 $=$ 製品の価值 $/$ 環境負荷 \\ ファクター $=\begin{aligned} & \text { 評価製品 (新) の環境効率 } / \text { 基準製品 (旧) } \\ & \text { の環境効率 }\end{aligned}$}

富士通グループではこの概念を元に、分子に直接製品価 值の評価製品と基準製品の新旧比率、分母には環境負荷の 新旧比率を採用し、環境効率ファクターと名付け社内に普 及させている。

$$
\text { 環境効率ファクター }=\underset{\text { 価値・サービス（新旧製品の比） }}{/ \text { 環境負荷（新旧製品の比） }}
$$

一度環境効率を算出してからファクターを導くのではな く、直接価値・サービスと環境負荷の新旧比を用いた理由 は、製品の価値・サービスを単独の值として算出するのが 困難と思われたためである。次章で詳細を述べるが、価 値・サービスを示す手段として、複数の製品仕様や機能值 を元データとして使用している。最終の目的が新旧製品の 比較であったため、これらの仕様值を無理に統合化し個々 の環境効率を導きだすよりも、仕様や機能の各向上度を計 測し分子の值として直接適用している。

1990年台初頭に提唱された「ファクター4」は、持続 可能な発展の追求のために、平均的生活レベルを 2 倍にす るのに半分の資源で澾成するという考えで立ち上がった。 このとき経済と環境は別々に目標を揭げており、最終的に 単一指標化している。現状の「環境効率」「ファクター」は、 絶対的な定義がなく、方法論で時に議論の対象となるが、 当初のファクター 4 のような大まかな概念から始まったこ とに話しを戻せばどれも間違いではない。元々のマクロ的 なコンセプトが、製品というミクロ単位に落とされ、算出 方法も各社で細分化された今、今度は初心に戻り、ファク ター4のような消費者に最も分かりやすく、心に訴えかけ ていくような方向性が今後必要なのではないかと思われる。 尚、本論は製品における環境効率へ議題を絞っているが、 企業活動全体の収支から環境効率を提示するのも例も数多 
く存在し、また産業連関表から企業・業界間の二酸化炭素 排出効率を比較する手法 ${ }^{5 ）}$ も盛んに研究されていること を言及したい。

\section{4. 価値・便益の算出}

\section{1 製品における価値・便益の考え方}

製品の価值・便益を算出するに当っては、前述したよう に環境効率やファクターの取り組みの中で、完全な形でな くとも価值・便益の考えを組み込むことが必須であると考 える。環境負荷のみ表現するならば学術的にも研究が進み、 既に多くの企業で浸透しているLCAの適用で要求は満た され、これに加え製品の価值・便益を合わせて表現したい ときに、環境効率やファクターの意義が生じると考えてい る。

次に、その方法論である。製品の価值・便益を数值化す るのに幾つかの方法が考えられ、製品価格、アンケート調 查、製品仕様や機能などの数值化について検討した。以下 に要点を述べる。

\section{（1）製品価格}

まず製品価格であるが、これは消費者が商品と向き合い、 最終的に決断に至り、取得するための代価であり、製品の サービス・機能・性能・品質・デザイン等の総合的な価值 尺度と言うことができると思う。しかしIT製品においては、 值段は刻々と変わることが多く、近年オープン価格と設定 されていることが少なくない。また、経年変化で調べる「環 境効率ファクター」では、インフレ率の考慮が必要である し、他国の製品と比較するときは為替変動の影響を受ける ことが避けられない。

\section{（2）アンケート調査}

次にアンケート調査結果を用いた分析であるが、内部トラ イアルでは製品の特質すべき項目を挙げ、重み付けをした 上で点数表化し、無作為にサンプルを抽出することで調査 を実施した。この方法によって結果を得ることは可能であ ると分かったが、莫大な労力と時間がかかり、また質問項 目と、点数化のための重み付け数值を決定するためには、 利害関係者でない第三者を加えるべきではないかという意 見が多かった。

\section{（3）製品仕様や機能などの数値化}

最後に製品仕様や機能に関するデー夕を数值化する方法に ついてで、カタログ等に記載されている機能やハードウエ アに起因する值の新旧製品向上率を求め、最終的に幾つか の向上率を抽出・平均化して算出した。次章で細分化して 説明するが、特にスキャナーのように製品機能が特定され
ている製品については「製品機能」から、パソコンや携帯 電話のように製品機能を容易に特定できない製品について は中心的な「ハードウエア仕様」の観点から評価を行った。

最終的には、製品を提供しているべンダーという立場で あることも考慮し、（3）の製品機能や仕様より価值・便益 を現状では数值化している。消費者の感じる価值・便益を 必ずしも正確に捉えきれていないという久点もあるが、算 出に使用するデー夕が公開されており透明性が高いことや、 アンケート調査のように多くの時間を要さず現実的である などの利点から現状の選択に至った。しかしながら、未だ 試行錯誤している側面もあり、今後も外部の情報を取り入 れ、より納得のいく評価をしていく予定である。

\section{2 製品機能を用いた算出}

製品のサービスが特定できるもの、いわゆる単機能製品 についてであるが、製品機能を数值化して算出する。ここ でいう製品機能とは消費者が実際に使用する機能であり、 後述のハードウエア仕様とは区別する。Table.1でスキャ ナーの価值・便益の定量化の例を示すが、光学性能を示す 基本解像度 - 読取速度、媒体処理性能を示す最大原稿开イ ズ・受け入れ原稿厚さ、デー夕処理性能を示す標準搭載さ れている画像処理・圧縮プログラム数などが製品機能であ り、光学、媒体処理、デー夕処理という多角化された観点 から評価を行っている $\left.{ }^{6)}, 7\right) 。$ 比較数值は、基準製品が(侏) PFUのFi-4110C (1999年発売) で、評価製品はFi-4120C (2002年発売)である。各機能の向上度を統合化するときは、

二乗和平均 $\left(=\sqrt{\frac{1}{n} \cdot \sum_{i=1}^{n} S i^{2}}\right)$ を用いており、この例の場合、

3 年間で価值・便益が新旧製品比で約 2.5 倍上昇という結 果を得た。

Table.1 Computation of service value or benefits of scanner

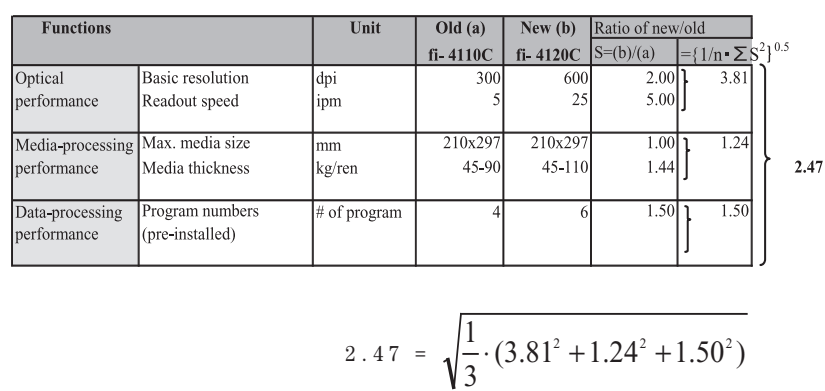

\section{3 ハードウェア仕様を用いた算出}

IT製品で数多くみられるのだが、製品のなかには機能 が特定できないものがある。例えばパソコンや携帯電話が その例で、パソコンでは文書作成、表計算、電子メール、 
Table.2 Computation of service value or benefits of personal computer

\begin{tabular}{|l|c|c|c|c|}
\hline Functions & unit & $\begin{array}{c}\text { Old (a) } \\
\text { FMV-5120NA/X }\end{array}$ & $\begin{array}{c}\text { New (b) } \\
\text { FMV-830NU/L }\end{array}$ & $\begin{array}{l}\text { Ratio of new/old } \\
\text { S=(b)/(a) }\end{array}$ \\
\hline CPU & GHz & $\mathbf{0 . 1 2}$ & $\mathbf{1 . 6}$ & $\mathbf{1 3 . 3}$ \\
\hline Memory & MB & $\mathbf{8}$ & $\mathbf{2 5 6}$ & $\mathbf{3 2 . 0}$ \\
\hline HDD & GB & $\mathbf{0 . 8 1}$ & $\mathbf{2 0}$ & $\mathbf{2 4 . 7}$ \\
24.6 & $=\sqrt{\frac{1}{3} \cdot\left(13.3^{2}+32.0^{2}+24.7^{2}\right)}$
\end{tabular}

インターネット閲覧はもとより、CDやDVDの作成・編 集・再生、ゲーム、音楽鑑賞、テレビ鑑賞など様々な機能 を持つことが特徵で、また場合によってはサーバー機能の ように他の製品群と同等に使用することもある。このよう に機能の特定できない製品については、スキャナーの例の ように機能面から数值化することが困難であるため、中心 的なハードウエア仕様を抽出しその向上度を用いて計算し ている。Table.2 で示すパソコンの場合ではCPU (Central Processing Unit, 中央演算処理装置）速度、購入時搭載メ モリー容量、標準ハードディスクドライブ容量を採用して おり ${ }^{1)}$, 8)、これらの仕様は一般に消費者がパソコンを購 入するときの重要な要素でもあるとも言える。比較数值は、 基準製品がFMV-5120NA/X (1996年発売) で、評価製品 はFMV-830NU/L (2004年発売) である。各機能の向上度 を統合化するときは、同じく二乗和平均を用いており、結 果として新旧製品比で約 25 倍向上となった。

\section{5. 環境負荷の算出}

近年、LCAに関する文献も増え、さらには日本LCA学 会も発足され、また様々な支援ソフトウエアが開発された ことから、「LCA実務入門」9）の冒頭に登場するような LCAの負のスパイラルにはまり、路頭に迷ってしまう評 価者は少なくなった。しかしながら、当社のように部品点 数の多い最終組立品を扱う企業にとって、LCAは膨大な 工数を要する評価であることは否めない。一方、環境効率 においては環境負荷の算出方法は様々で、必ずしもライフ サイクルシンキングは義務付けられていない。我々が LCA 重要視する理由は以下にある。

Figure.4にノートパソコン FMV-718NU4/B (2003年発 売）における各ライフステージでの $\mathrm{CO}_{2}$ 排出量を示す ${ }^{10)}$ 。 エコリーフの算出結果をさらに製造では素材製造・部品製 造・加工レベル、使用では各モードレベルまで細分化した ものであるが、製品そのものの環境負荷を示す「素材製造」 「製品製造」両ステージの合計が、全体の $70 \%$ 程度の $\mathrm{CO}_{2}$ 排出量を占めていた。一般に考えられがちな、電気製品で は使用ステージの負荷がほとんどであるため、使用ステー ジの消費電力で環境負荷評価が可能であるという考えは、

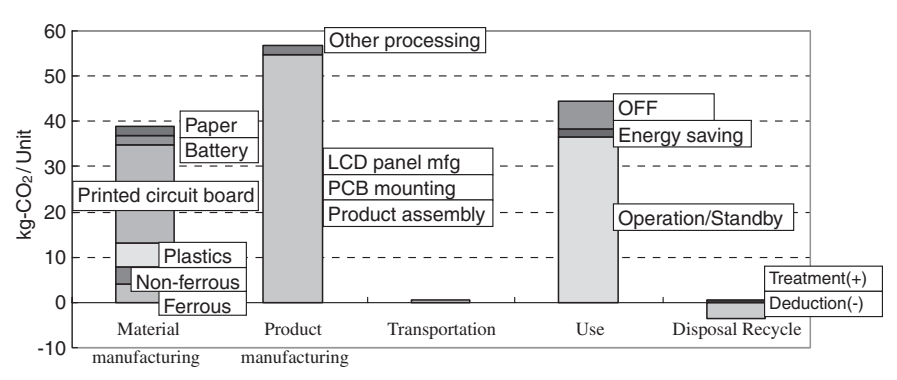

Figure.4 Life Cycle $\mathrm{CO}_{2}$ emission of notebook personal computer

IT製品において必ずしもあてはまらないことがわかる。 これは、IT製品で多く使用されている半導体や多層プリ ント基板、LCDの製造工程が多くのエネルギーを要する 工程であり、これらの負荷が製品全体の評価の中でも大き なウエイトを占めているからである。こういった議論の結 果、富士通グループでは分母となる環境負荷に算出には、 LCA 手法を全面的に採用している。

\section{1 エコリーフ環境ラベルの適用}

エコリーフ環境ラベル ${ }^{11 ）}$ とは、国際標準化機構ISOの 類型でタイプIII環境ラベルに属し、LCA手法に基づき製 品・サービスの全ライフサイクルに渡る定量的な環境情報 を開示する環境ラベルである。社団法人産業環境管理協会 が運営母体となり 2002 年より本格運用が開始され、2005 年5月現在までに製品分類別基準（PSC: Product Specification Criteria）が36件制定され、31社から 256 製品のラ ベルが発行されている。

環境効率ファクターの環境負荷算出には、エコリーフに よるLCI算出結果の採用を優先しているが、これは多くの 仮定を要する組立製品のLCAにおいて、より高い透明性 と信頼性を確保するためである。まず透明性について、エ コリーフではLCA算出基準の作成の段階から関係企業が 協議し、製品区分ごとに製品分類別基準と呼ばれるルール を設定する。ここで対象製品の定義、システム境界、各ラ イフサイクルステージでのシナリオ、データ収集・加工方 法、公開範囲等を明文化し、ホームページを通じて一般へ 公開している。さらにプログラム内で第三者よる検証行為 を踏まえることで、対象製品の算出結果は信頼性を増して おり、個別ラベルの詳細結果も同様にホームページ上に公 開されている。

富士通グループにおいては、トライアル段階からプログ ラムに参画し、2003年にパソコン業界として初めてノー トパソコンでエコリーフを取得、その後 2004 年には光磁 気ディスクドライブ（MO）、2005年度にはデスクトップ パソコン及びパソコンディスプレィにおいて対象機種を拡 大し、2005年 4 月までに合計 24 製品の登録を完了してい る ${ }^{12)}$ 。Figure.5 に本論分の環境効率ファクター算出例示 


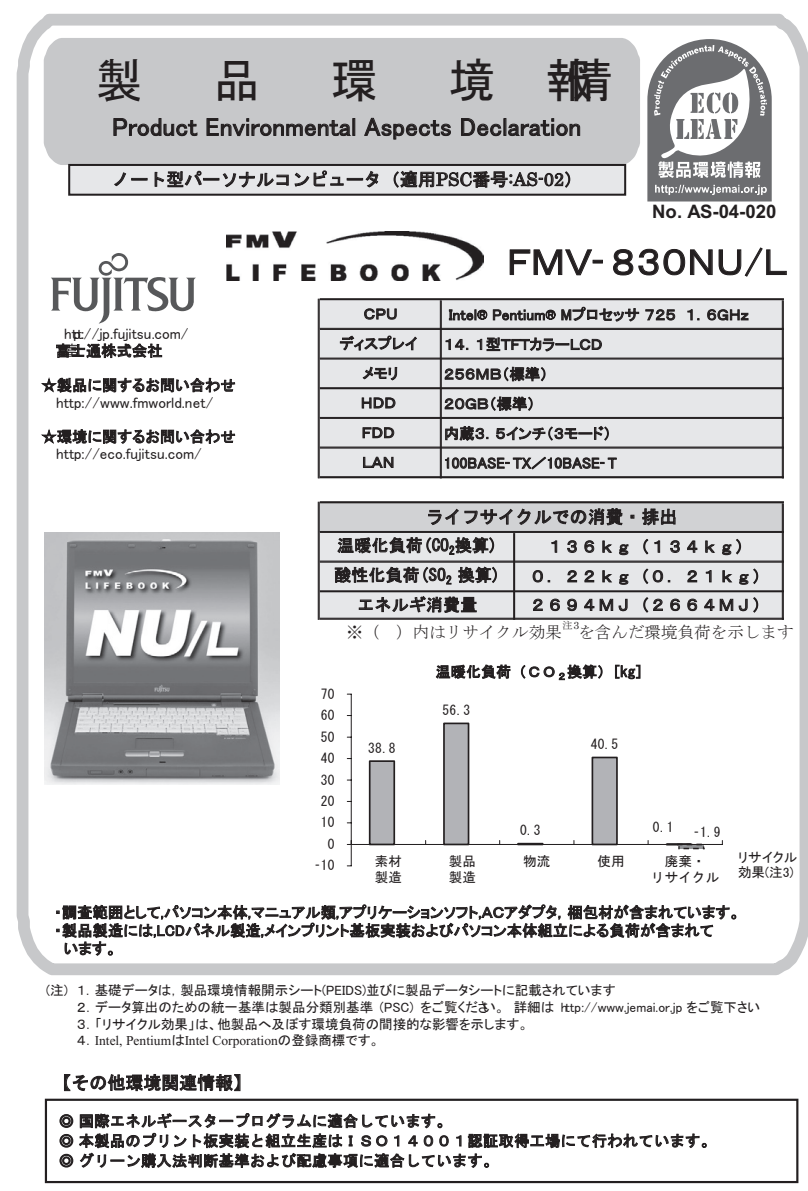

Figure.5 Product Environmental Aspects Declaration(PEAD) sheet of EcoLeaf Environmental Label (Example of Notebook PC, FMV$830 \mathrm{NU} / \mathrm{L})$

機種である FMV-830NU/L (2004年発売) の、エコリーフ 公開書類の一部を示す。またパソコン事業体においては、 製品環境データ集積システム認定（システム認定）を同じ く産業環境管理協会より取得しており、自社内でラベルを 作成・検証・発行する仕組みをマニュアル化と共に構築す ることによって、より精度の高いLCA結果の公開に努め ている13)。

\section{2 社内基準における LCAの適用}

エコリーフを取得していない製品群に関しては、社内基 準に準じたLCA 結果を用いて環境効率ファクターを算出 している。この基準の特徴を三点述べる。第一に製品群ご とに算出基準を定めている点である。従来は包括的な LCAガイドラインのみ存在していたため、設計者により 設定条件がばらつくことがあったが、近年、製品群個別に カスタマイズした算出条件を設定することで、より精度の 高いLCA算出を設計者が短時間で行うことが可能となった。 第二に原単位データベースである。富士通研究所の算出し た産業連関表分析より得られた2000項目を越える原単位 を中心に、自社工場の積み上げデー夕、文献調查デー夕を 加えたハイブリット型の原単位ベータベースを採用してい
Table.3 Evaluation example of printed circuit board considering the number of surface-mounted components

\begin{tabular}{|c|c|c|c|c|c|}
\hline Parts name & Unit & $\begin{array}{l}\text { Number on } \\
\text { PCB }\end{array}$ & & Base unit & \\
\hline Bare board & $\mathrm{mm}^{2}$ & 3610 & & $x x x$ & \\
\hline MPU & piece & 2 & & 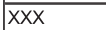 & \\
\hline DRAM & piece & 1 & & $x x x$ & \\
\hline SRAM & piece & 1 & & $x x x$ & \\
\hline ROM & piece & & & & \\
\hline other LSI & piece & 10 & & $x x x$ & \\
\hline Transistor & piece & 13 & & $\mathrm{XXX}$ & \\
\hline & $\begin{array}{l}\text { piece } \\
\text { piece }\end{array}$ & & & & \\
\hline Silicon diode & piece & 60 & $x$ & $x x x$ & $\begin{array}{l}\text { Environmental loads } \\
\text { of Printed Circuit Board }\end{array}$ \\
\hline Photocoupler & piece & & & & \\
\hline Resistor & piece & 332 & & $X X X$ & \\
\hline Capacitor & piece & 371 & & $x x x$ & \\
\hline Coil & piece & & & & \\
\hline Connector & piece & 15 & & $x x x$ & \\
\hline Switch & piece & & & & \\
\hline Fuse & piece & & & & \\
\hline $\begin{array}{l}\text { Button battery } \\
\text { other electronic parts }\end{array}$ & $\begin{array}{l}\text { piece } \\
\text { piece }\end{array}$ & & & & \\
\hline
\end{tabular}

Table.4 Integrated environmental loads using EcoLeaf inventory results and LIME

\begin{tabular}{|c|c|c|c|}
\hline & $\begin{array}{c}\text { FMV-5120NA/X } \\
\text { (point } / \mathrm{kg} \text { ) }\end{array}$ & $\begin{array}{c}\text { FMV-830NU/L } \\
\text { (point } / \mathrm{kg} \text { ) }\end{array}$ & $\begin{array}{l}\text { Reduction } \\
(\%)\end{array}$ \\
\hline Production & 246.4 & 217.7 & $12 \%$ \\
\hline Distribution & 7.1 & 1.8 & $75 \%$ \\
\hline [Üse- & 122.1 & 73.5 & $40 \%$ \\
\hline Disposition & -2.9 & -2.9 & $0 \%$ \\
\hline Sum & 372.7 & 290.0 & $22 \%$ \\
\hline
\end{tabular}

る。第三に実装回路基板の評価についてであるが、富士通 グループの扱うIT製品では集積度の高い半導体が高密度 に実装されており、質量的には全体からみて微量だが、環 境負荷として多きいウエイトを占めることが考えられる。 このため、製品群によって可能な限り実装部品の種類を分 類し、Table.3に示すようにこれらの数量を計測すること で実装部品レベルまで着眼した評価を実施している。

\subsection{LIMEによる統合化指標の活用}

エコリーフ環境ラベルや社内基準によるインベントリ分 析結果を元に、LIME (Life cycle impact assessment method based on endpoint modeling）を活用したインパ クト評価を環境効率ファクターに取り入れている。従来の 二酸化炭素排出量による評価から、様々な消費・排出項目 を統合化し単一指標化することで、包括的な環境負荷を把 握するのが目的で、布施 (2004) ${ }^{8)}$ によりエコリーフと LIMEを組み合わせ、環境効率ファクターを算出した例が 発表されている。ここでは、基準製品をFMV-5120NA/X （1996年発売）、評価製品をFMV-830NU/L (2004年発売) とし、エコリーフインベントリ分析結果を統合化した算出 結果をTable. 4 に示す。結果として評価製品は基準製品に 比べ、統合化指数が $22 \%(=1-(290 / 373))$ 減少している。

\section{6. 環境効率ファクターの算出例}

4.3 章 Table. 2 の価值・便益の算出結果、及び 5.3 章 Table.4で得た統合化環境負荷結果を用いて、ノートパソ 
コン FMV-5120NA/X と FMV-830NU/Lの環境効率ファク ターの算出例を提示する。結果より対象のノートパソコン は8年間でファクター 32 を達成している。

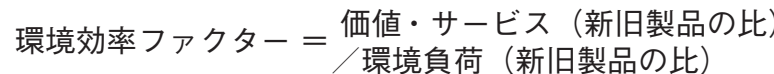

$$
\begin{aligned}
& =24.6 \text { 倍 / (1-0.22) 倍 } \\
& =32 \text { 倍 }
\end{aligned}
$$

7. まとめ

LCA と共に環境効率の適用が企業において急速に進む 一方、消費者の視点に立った環境指標の提示が今後の課題 であると思う。特に製品の環境効率において、各社間の算 出方法の統一性がとれないまま複雑化が進んでいるため、 ファクター值の安易な比較による混乱が懸念される。製品 群ごとの便益算出のガイドライン策定や、環境負荷評価に おいてはGraedel (1995) 14) の提唱するマトリックスを用 いた半定量的LCAによる算出方法の簡素化など必要であ るかもしれない。

企業の社会的責任（CSR）のトリプルボトムラインを成 す「経済性」と「環境」を同時に表現できる環境効率の概 念は企業にとって受け入れやすく、事業活動や製品・サー ビスを対象に、開発・試算段階から適用段階へと推移して いる。今後、トリプルボトムラインのもう一つの要素であ る「社会性」も組み込まれた指標が開発・公開されていく ことが予測されるが、これらの指標が持続可能な発展の一 里塚となるよう積極的に貢献していきたい。

\section{引用文献}

1）富士通株式会社：“2004富士通グループ環境経営報告 書” (2004) pp.26-30

2) Ebisu, K. and Suzuki, S.: The Sixth Internationa Conference on EcoBalance, Tsukuba, (2004), pp.585-586

3）富士通株式会社：“2002富士通グループ環境報告書” (2002) p.23

4）社団法人産業環境管理協会：“製品に関する「環境効率・ ファクター」の手引き”, (2004) pp.5-6

5) Tahara, K., Yamaguchi, K. Sagisaka, M., and Inaba, A.: The Sixth International Conference on EcoBalance, Tsukuba, (2004), pp.269-270

6) Fuse, K., Horikoshi, Y., Kumai, T., and Taniguchi, T.: 3rd International Symposium on Environmentally Concious Design and Inverse Manufacturing (EcoDesign 2003), Tokyo, (2003), pp.356-359

7）富士通株式会社：“2003富士通グループ環境経営報告 書” (2003) pp.23

8) Fuse, K., Oikawa, S., and Ebisu, K:. The Sixth International Conference on EcoBalance, Tsukuba, (2004), pp.259-262

9）LCA実務入門編集委員会, “LCA実務入門”, 社団法人産 業環境管理協会, 東京都, (1998), pp.1-5

10) Fuse, K. and Oikawa, S.: Environmental Management, 39 (11), (2003), pp.17-25（布施健介, 及 川聡：環境管理, 39(11), (2003), pp.17-25 [in Japanese])

11）稲葉敦監修,LCA シリーズ LCAの実務”, 社団法人産 業環境管理協会, 東京都, (2005), pp.167-168, 174-180,

12）社団法人産業環境管理協会 : “事業者ごとのラベル登 録済み製品一覧”, エコリーフ環境ラベル（オンライン）, 入手先 <http://www.jemai.or.jp/CACHE/ecoleaf_ prodbycmp_companyobj21.cfm>, (参照2005-06-15)

13) Endo, S., Kasahara, M., and Fuse, K.: MAGAZINE FUJITSU 2003-11, 54 (6), (2003), pp.480-485（遠藤秀一, 笠原雅治, 布施健介：雑誌FUJITSU 2003年11月号, 54 (6), (2003), pp.480-485 [in Japanese])

14) Graedel, T. and Allenby, B, "Industrial Ecology", Prentice Hall, New Jerser, (1995), pp.129-132 